\title{
Antibacterial Activity and Chemical Composition of Essential Oils from Some Galium (Rubiaceae) Species Against Pathogenic Bacteria
}

\author{
Filiz Yağız' ${ }^{1}$, Rifat Battaloğlu²*, Sedef İlk ${ }^{3}$, Ahmet Savran ${ }^{4}$ \\ ${ }^{I}$ ZNO Chemistry Ltd. Sti, Bor Organized Industrial Zone, 51700 Bor/Niğde, Turkey \\ ${ }^{2}$ Department of Chemistry, Faculty of Science and Art, Niğde Ömer Halisdemir University, 51200 Niğde, Turkey. \\ ${ }^{3}$ Central Research Laboratory, Niğde Ömer Halisdemir University, 51240 Niğde, Turkey \\ ${ }^{4}$ Department of Biology, Faculty of Science and Art, Niğde Ömer Halisdemir University, 51200 Niğde, Turkey. \\ A R T I C L E I N F O \\ Research Article \\ Received 12 July 2017 \\ Accepted 20 September 2017 \\ Keywords: \\ Essential oils \\ Galium incanum \\ Galium dieckii \\ Galium aladaghense \\ Antimicrobial activity. \\ *Corresponding Author: \\ E-mail: rbattaloglu@ohu.edu.tr \\ A B S T R A C T \\ In this work, chemical composition and antimicrobial activity of the essential oils of \\ Galium incanum, Galium dieckii ve Galium aladaghense were firstly reported. The \\ essential oils were obtained from the all parts of the plant by hydrodistillation and \\ analyzed by using GC-MS. Antimicrobial activity of synthezied essential oils was carried \\ out against 5 pathogen bacteria Escherichia coli (E. coli) ATCC 25922, Staphylococcus \\ aureus (S. aureus) ATCC 25923, Pseudomonas syringae pv. tomato (P. syringae) \\ DC300, Salmonella enterica serotype Typhmurium (S. typhmurium) SL 1344 and \\ Streptococcus mutans (S. mutans) ATCC 25175. According to the results, it was \\ determined that isolated essential oils comprised of 61 compounds. Compounds of \\ essential oils included that structure monoterpene $(8.2 \%)$, monoterpenoid $(14.75 \%)$ and \\ sesquiterpene (14.75\%). Unclassified compounds have been identified as other \\ compounds. From the antimicrobial activity was observed that the isolated essential oil \\ from Galium incanum, Galium dieckii ve Galium aladaghense exhibited a potent \\ inhibitory effect against all gram negative and gram positive bacteria with diameter of \\ inhibition zones ranging from 4.3 to $12.3 \mathrm{~mm}$. Essential oil of Galium aladaghense \\ indicated that high antimicrobial activity on all bacteria than Galium incanum and Galium \\ dieckii.
}

DOI: https://doi.org/10.24925/turjaf.v5i11.1330-1333.1414

\section{Introduction}

Plants have been used medicinally all over the world for many centuries. The intake of fresh fruits, vegetables and tea rich in natural antioxidants has been connected with prevention of cancer and cardiovascular diseases (Willcox et al, 2004). Approximately $60 \%$ of the commercially available anti-tumor and anti-infective agents are of natural origin (Cragg et al., 1997).

Galium species are one of the most important species of Rubiaceae family. The genus Galium is comprised of approximately 1300 species and 101 species are represented in Turkey by divided into 10 sections. Galium species called "Yogurt herb" due to contain an enzyme that coagulate the milk (Başer at al., 2004). Galium species include flavonoids, alkaloids and iridoids (Iavarone et al, 1983; de Rosa et al., 2000). Iridoids are considered as a group of terpenoids which has biological activities. Extract of this plants is used for the treatment of stomach disorders, neuroprotective, epilepsy, hysteria and gout (Menković et al., 2011). Therefore, the analysis of the oil components of Galium species is considered important.

In our study have been reported that composition of essential oils of Galina incanum, Galium dieckii and
Galium aladaghensis which are endemic plants with relative percentage amount of any of the components and biological activity of isolated essential oil obtained Galium species against five pathogenic bacteria. To the best of our knowledge, the composition and antimicrobial activity of essential oil of Galium incanum, Galium dieckii and Galium aladaghensis has not previously been reported.

\section{Materials and Methods}

Luria Bertoni (LB) agar, Mueller Hinton agar, DMSO, n-hexane, $\mathrm{Na}_{2} \mathrm{SO}_{4}$ were purchased from Sigma-Aldrich. All plant samples (Galina incanum, Galim dieckii and Galim aladaghensis) were collected in Niğde Region. The tested microorganisms (Escherichia coli (E. coli) ATCC 25922, Staphylococcus aureus (S. aureus) ATCC 25923, Pseudomonas syringae pv. tomato (P. syringae) DC300, Salmonella enterica serotype Typhmurium (S. typhmurium) SL 1344 and Streptococcus mutans (S. mutans) ATCC 25175) were provided by Biology Department of Niğde Ömer Halisdemir University. 
Plant Material and Isolation of Essential Oils

From the tested plant samples, Galium dieckii and Galium aladaghense are endemic plants and also located in the Central Anatolia Region. Plants (Galina incanum, Galim dieckii and Galim aladaghensis) were collected in 2013 and identified by Dr. Ahmet SAVRAN. The dried and powdered plant sample (100 g) was subjected to hydro-distillation using a Clevenger-type apparatus for 4 h. The resulting essential oils were dissolved in $0.5 \mathrm{~mL} \mathrm{n}$ hexane (HPLC grade) and dried over anhydrous sodium sulfate $\left(\mathrm{Na}_{2} \mathrm{SO}_{4}\right)$ and stored at $4^{\circ} \mathrm{C}$ in a sealed vial until use. All experiment was performed triplicate (Hammami et al., 2015).

\section{GC-MS Analysis Conditions}

The essential oil was analysed by using ThermoDSQII GC-MS equipped with a T-WAXMS capillary column $(60 \mathrm{mx} 0.32 \mathrm{mmx} 0.25 \mathrm{~m})$ For gas chromatographymass spectrometry (GC-MS) detection, an electron ionization system with ionization energy of $70 \mathrm{eV}$ was used. Helium was the carrier gas at a flow rate of 1 $\mathrm{mL} /$ minute. Injector and MS transfer line temperatures were set at $220^{\circ}$ and $290^{\circ} \mathrm{C}$, respectively. The programme was used at $50-150^{\circ} \mathrm{C}$ at a rate of $3^{\circ} \mathrm{C} /$ minute. Diluted samples $(1 / 100, \mathrm{v} / \mathrm{v}$, in methylene chloride) of $1.0 \mu \mathrm{L}$ were injected manually and in splitless mode. The components were identified based on the comparison of their relative retention time and mass spectra with those of standards, MAINLAB, Wiley $7 \mathrm{~N}$ and Replic library data of the GC-MS system and literatüre data. The results were also confirmed by the comparison of the compounds' elution order with their relative retention indices on non-polar phases reported in the literature (Sarikurkcu et al., 2013).

\section{The Tested Microorganisms}

The following microorganisms including $E$. coli ATCC 25922, S. aureus ATCC 25923, P. syringae DC300, S. typhmurium SL 1344 and S. mutans ATCC 25175 were used as the tested microorganisms. Bacteria were maintained on Luria Bertani (LB) agar culture medium at $4^{\circ} \mathrm{C}$. All the tested microorganisms were subcultured on $\mathrm{LB}$ broth medium at $37^{\circ} \mathrm{C}$ for $24 \mathrm{~h}$ before the antimicrobial activity assay.

\section{Antibacterial Activity Test}

Antimicrobial activities of the synthesized essential oils of Galium incanum, Galium dieckii ve Galium aladaghense against the sensitive organisms Staphylococcus aureus and Streptococcus mutans as Gram-positive bacteria and Escherichia coli, Pseudomonas syringae pv. tomato and Salmonella enterica serotype Typhmurium. as Gram-negative bacteria were determined by using disc-diffusion method according to Clinical and Laboratory Standards Institute with small modifications (CLSI, 2012). 0.5 McFarland standard was used as a reference to adjust the turbidity of microorganisms. The tested compounds were dissolved in dimethylsulfoxide [(DMSO) which has no inhibition activity]. The essential oil concentration in DMSO were adjusted to $15 \mathrm{mg} / \mathrm{mL}$. The samples were sterilized by UV irradiation for $30 \mathrm{~min}$ before incubation. Microorganism suspensions of $100 \mu \mathrm{l}$ were inoculated $\left(10^{6}\right.$ cells $\left./ \mathrm{mL}\right)$ onto Müller-Hinton medium. Filter discs (6 $\mathrm{mm}$ in diameter) containing with essential oils (Galium incanum (A), Galium dieckii (B), Galium aladaghense (C)) were placed on an inoculated petri plate and incubated at $37^{\circ} \mathrm{C}$ for $24 \mathrm{~h}$. Only DMSO solvent containing discs was used as a negative control. The diameter of inhibition zone around of the disc was calculated after incubation. All experiments were repeated triplicate and mean values were calculated. (MIC)

Determination of Minimum Inhibition Concentration

A microdilution broth susceptibility assay was used as recommended by Clinical and Laboratory Standards Institute (CLSI, 2010). with small modifications for the determination of the Minimum inhibition concentrations (MICs). Each strain was tested with sample that was serially diluted in LB broth to obtain concentrations ranging from $0.1-10 \mathrm{mg} / \mathrm{mL}$ in DMSO. The samples were previously sterilized by UV irradiation was inoculated with $50 \mathrm{~mL}$ suspension of $10^{6} \mathrm{CFU} / \mathrm{mL}$ of the tested microorganisms and incubated for $24 \mathrm{~h}$ at $37^{\circ} \mathrm{C}$. Another culture medium without adding microorganisms suspension was prepared as the negative control. The MIC value was determined as the lowest concentration (highest dilution) of the sample showing no visible growth at which the tested microorganisms did not demonstrate any visible growth after incubation. Cells from the tubes showing no growth were subcultured on LB agar plates to determine if the inhibition was reversible or permanent.

\section{Results and Discussion}

\section{Characterization of Essential Oils}

61 compounds were identified from results of GCMS analyses of essential oils of Galium incanum (A), Galium dieckii (B), Galium aladaghense (C) (Table 1). Compounds of essential oils included that structure momoterpen (8.2\%), momoterpenoid (14.75\%) and sesquiterpene (14.75\%). From the results, which was observed that five compounds are monoterpenes $(\alpha$ terpinene, $\alpha$-pinene, $\beta$-pinene, limonene, tymole), nine compounds are monoterpenoid (linalool, camphor, Lborneol, borneol, myrtenol, 1,8-cineole, carvacrol, eugenol, pinocarvone), nine compounds are sesquiterpene (cipren, $\alpha$-cedrene, $\beta$-caryophyllen, trans- $\beta$-pharnesene, $\alpha$ humulene, caryophyllen oxide, cubenol, zerumbone, ciscis-calamenene). Excluding of this compounds were identified as other compounds (Shahzad, 2015).

The essential oil of Galium incanum was predominated by monoterponoid (13.2\%), sesquiterpene (9\%) and monoterpenes $(8.1 \%)$, respectively. On the other hand, the oil of Galium dieckii and Galium aladaghense was comprised of monoterponoid (12.2 and 11.3\%), monoterpenes (5.9 and 22.7\%) and sesquiterpene (5.7 and $5 \%$ ), respectively. Major components of the oils of 
Galium incanum, Galium dieckii and Galium aladaghense were eugenol $(7.8,8.1$ and $6.9 \%), \alpha$-humulene $(7.8,5.3$, $3.2 \%)$ and thymol $(7.4,5.7$ and $21.4 \%)$. The essential oil of Galium aladaghense can be considered as an aromatic plant more than Galium incanum and Galium dieckii due to comprise high content of thymol.

\section{In vitro antimicrobial activity}

The in vitro antimicrobial activity of Galium incanum (A), Galium dieckii (B), Galium aladaghense (C) essential oil was evaluated by disc diffusion method against Gram-positive (Staphylococcus aureus and Streptococcus mutans) and Gram negative bacteria (Escherichia coli, Pseudomonas syringae and Salmonella typhmurium). According to the results shown in Table 2, the essential oil exhibited a potent inhibitory effect against all gram negative and gram positive bacteria $(E$. coli, $P$. syringae, $S$. typhmurium, $S$. aureus and $S$. mutans) with diameter of inhibition zones ranging from 4.3 to $12.3 \mathrm{~mm}$. The essential oil exerted a broad antimicrobial spectrum and showed a high antimicrobial effect on S. mutans, E.coli and $S$. typhmurium with the diameter of inhibition zones of $12.3,11.5$ and $11.3 \mathrm{~mm}$, respectively. Essential oil of Galium aladaghense indicated that high antimicrobial activity on all bacteria than Galium incanum and Galium dieckii.

Antimicrobial activity of essential oils increased by increasing content of thymol component. The essential oil of Galium aladaghense was comprised of more thymol content than others (Baser et al., 2004).

All tested microorganisms are of clinical importance. The usefulness of this method is limited to the generation of preliminary quantitative data only, as the hydrophobic nature of most essential oils and plant extracts components prevents their uniform diffusion through the agar medium. Based on this, it is recommended to use an emulsifier such as DMSO, to assure contact between the microorganism and the possible antimicrobial agent (Samusenko, 2008). Essential oil exhibited antimicrobial activity against the tested strains, but in variable degree (Table 2).

Table 1 Compounds of essential oils.

\begin{tabular}{|c|c|c|c|c|c|c|c|c|c|}
\hline Compound & RI & $\% \mathrm{~A}$ & $\% \mathrm{~B}$ & $\% \mathrm{C}$ & Compound & RI* & $\% \mathrm{~A}$ & $\% \mathrm{~B}$ & $\% \mathrm{C}$ \\
\hline trans-2-hexenal & 801 & 1.5 & 2.3 & - & $\beta$-ionene & 1487 & - & - & 0.2 \\
\hline Heptanal & 903 & - & 1.8 & 0.7 & $\alpha$-campholene aldehyde & 1500 & 1.1 & 0.9 & 0.2 \\
\hline Cyclopentene & 931 & 0.9 & 0.6 & - & Benzaldehyde & 1541 & 0.3 & 0.1 & 0.2 \\
\hline 3-octanone & 984 & - & 0.2 & 0.2 & Caryophyllen oxide & 1555 & - & - & 0.6 \\
\hline$\alpha$-terpinene & 1019 & 0.3 & - & 0.7 & Elemicin & 1558 & - & - & 0.2 \\
\hline$\alpha$-pinene & 1032 & 0.1 & 0.2 & - & Octanol & 1562 & 2.7 & 9.7 & 0.6 \\
\hline n-octanol & 1063 & - & - & 0.3 & 5-metyl furfural & 1585 & 0.9 & - & 0.2 \\
\hline Hexanal & 1093 & 0.7 & 0.3 & 0.4 & Pinocarvone & 1586 & - & - & 0.9 \\
\hline Linalool & 1098 & - & 0.2 & - & Cubenol & 1648 & 0.6 & - & 0.2 \\
\hline$\beta$-pinene & 1118 & 0.2 & - & 0.6 & Carvenone & 1737 & 0.4 & 0.3 & 0.3 \\
\hline Camphor & 1147 & 1.2 & 0.2 & 0.5 & Zerumbone & 1754 & - & - & - \\
\hline L-Borneol & 1165 & 3.2 & 1.8 & - & Octadecane & 1800 & 0.2 & 1.9 & 0.4 \\
\hline Borneol & 1171 & - & - & 0.3 & cis-calamenene & 1853 & 0.5 & - & - \\
\hline Myrtenol & 1194 & - & 0.7 & 0.5 & Hexanoic acid & 1870 & 0.4 & 6.8 & 0.3 \\
\hline Limonene & 1203 & 0.1 & - & - & 1-hexadecanol & 1874 & 0.6 & 0.4 & 1.6 \\
\hline İsoamyl alcohol & 1212 & 0.3 & - & 0.5 & hexadekanoic acid & 1929 & 21.6 & - & 6.4 \\
\hline 1,8-cineole & 1213 & 0.6 & - & - & Tetradecanal & 1933 & 1.7 & - & 0.6 \\
\hline Nonanoic acid & 1267 & 0.1 & 0.3 & - & Eicosane & 1999 & 0.7 & 0.3 & 0.4 \\
\hline Carvacrol & 1298 & 0.4 & 1.2 & 2.4 & Phytol & 2102 & - & - & 1.5 \\
\hline 2-heptanol & 1320 & 0.1 & - & 0.3 & Thymole & 2205 & 7.4 & 5.7 & 21.4 \\
\hline Eugenol & 1360 & 7.8 & 8.1 & 6.9 & Tricosane & 2300 & - & 6.8 & 0.4 \\
\hline (Z)-3-hexenol & 1391 & 0.2 & - & - & Decanoic acid & 2300 & 1.7 & 2.8 & - \\
\hline Cipren & 1398 & - & - & 0.4 & Pentacosane & 2499 & - & - & 0.2 \\
\hline Nonanal & 1400 & 1.2 & 2.4 & 0.8 & Metyl linoleate & 2509 & 0.2 & - & 0.7 \\
\hline Dodecanal & 1409 & 11.5 & - & 2.6 & Heptacosane & 2700 & 0.9 & 0.2 & - \\
\hline$\alpha$-cedrene & 1411 & - & - & 0.6 & Tetradecanoic acid & 2713 & - & 3.6 & - \\
\hline$\beta$-caryophyllen & 1426 & - & 0.2 & - & Pentadecanoic acid & 2822 & 0.3 & - & 0.1 \\
\hline Geranyl acetone & 1445 & - & - & 0.7 & Nonacosane & 2900 & 1.7 & - & - \\
\hline Trans- $\beta$-farnesene & 1449 & 0.1 & 0.2 & - & Oleic acid & 3200 & 1.3 & 0.2 & - \\
\hline 1-octene-3-ol & 1452 & 0.7 & - & 0.4 & Linoneic acid & 3290 & - & 2.1 & 4.7 \\
\hline$\alpha$-humulene & 1454 & 7.8 & 5.3 & 3.2 & & & & & \\
\hline
\end{tabular}

RI: Retention Index A:Galium incanum, B: Galium dieckii, C: Galium aladaghense 
Table 2 Antimicrobial activity of Galium incanum (A), Galium dieckii (B), Galium aladaghense (C) in DMSO against the sensetive gram negative and gram positive bacteria

\begin{tabular}{|c|c|c|c|c|c|c|c|}
\hline \multirow[t]{2}{*}{ Microorganisms } & \multirow[t]{2}{*}{ Strain } & \multicolumn{3}{|c|}{$\begin{array}{l}\text { Inhibition zone } \\
(\mathrm{mm})\end{array}$} & \multicolumn{3}{|c|}{$\begin{array}{l}\text { Minimum inhibitory concentrations } \\
(\mathrm{MIC})(\mathrm{mg} / \mathrm{mL})\end{array}$} \\
\hline & & $\mathrm{A}$ & $\mathrm{B}$ & $\mathrm{C}$ & $\mathrm{A}$ & $\mathrm{B}$ & $\mathrm{C}$ \\
\hline E. coli & ATCC 25922 & $9.8 \pm 0.6$ & $9.3 \pm 0.7$ & $11.5 \pm 0.8$ & $0.4 \pm 0.02$ & $0.4 \pm 0.02$ & $0.8 \pm 0.02$ \\
\hline P. syringae & DC 3000 & $4.3 \pm 0.4$ & $7.9 \pm 0.5$ & $10.2 \pm 0.6$ & $3.2 \pm 0.06$ & $1.6 \pm 0.03$ & $1.2 . \pm 0.03$ \\
\hline S. typhmurium & SL 1344 & $7.1 \pm 0.5$ & $8.2 \pm 0.6$ & $11.3 \pm 0.7$ & $2.4 \pm 0.04$ & $1.6 \pm 0.03$ & $1.6 \pm 0.03$ \\
\hline S.aureus & ATCC 25923 & $7 \pm 0.5$ & $9.1 \pm 0.7$ & $10 \pm 0.6$ & $2.4 \pm 0.04$ & $1.6 \pm 0.02$ & $1.2 \pm 0.02$ \\
\hline S. mutans & ATCC 25175 & $8.9 \pm 0.6$ & $9.8 \pm 0.7$ & $12.3 \pm 0.9$ & $0.8 \pm 0.04$ & $0.4 \pm 0.03$ & $0.4 \pm 0.02$ \\
\hline
\end{tabular}

\section{Minimum Inhibitory Concentration (MIC)}

MIC values of essential oil against the testes strains are shown in Table 2. These Riaz et al. 2012 results demonstrated that this oil displayed potential antibacterial and microbicidal property. In general, the MIC values of the essential oil against the tested microorganisms ranged from $0.4 \mathrm{mg} / \mathrm{mL}$ to $3.2 \mathrm{mg} / \mathrm{mL}$. By considering the results of inhibition zone assay in Table $1, S$. mutans was the most sensitive one in the tested microorganisms. The data indicated that the Gram-negative E. coli and the Grampositive $S$. mutans were the most sensitive strains tested to the essential oils of Galium incanum, Galium dieckii, Galium aladaghense. Gram-negative E. coli is known to highly resistant even to synthetic drugs due to a very restrictive outer membrane barrier (Piggot et al., 2011). However, essential oil of Galium aladaghense inhibits growth of this pathogen bacterium. Gram-positive $S$. mutans is the most common species as a human pathogen. Tested essential oils of all Gallium species showed prominent antimicrobial activity against this pathogen bacterium.

\section{Conclusions}

To the best of our knowledge, this is the first report of the composition and antimicrobial activity of essential oil of Galium incanum, Galium dieckii, Galium aladaghense. Considering the results of the GCMS analysis of essential oils from Galium incanum, Galium dieckii, Galium aladaghense, the data are suitable for the evaluation of the components of oils and compare the components content to antimicrobial affectivity. In general, the results show that with increasing monoterpen components, especially thymol groups, increased inhibition of growth of bacteria (Baser et al., 2004). The essential oil of this Galium species can be used as antimicrobial agent in medicine, pharmacy or biotechnological area for the future applications.

\section{References}

Baser, KHC, Özek T, Kırımer N, Deliorman D, Ergun F. 2004 Composition of the essential oils of Galium aparine L. and Galium odoratum (L.) Scop. from Turkey. Journal of Essential Oil Research, 16(4), 305-307.

Clinical and Laboratory Standards Institute. 2012. Performance Standards f or Antimicrobial Disk Susceptibility Tests; Approved Standard-Eleventh Edition. CLSI document M02A11. Wayne, PA: Clinical and Laboratory Standards Institute.
Clinical and Laboratory Standards Institute. 2010. Methods for Antimicrobial Dilution and Disk Susceptibility Testing. Approved Guideline-Second Edition. CLSI document M45A2. Wayne, PA: Clinical and Laboratory Standards Institute.

Cragg GM, Newman DJ, Weiss RB. 1997. Coral reefs, forests, and thermal vents: the worldwide exploration of nature for novel antitumor agents. In Seminars in oncology, 24(2): 156-163.

Hammami I, Smaoui S, Hsouna AB, Hamdi N, Triki MA. 2015. Ruta montana L. leaf essential oil and extracts: characterization of bioactive compounds and ppression of crown gall disease. EXCLI journal, 14, 83.

Menković N, Šavikin K, Tasić S, Zdunić G, Stešević D, Milosavljević S., \& Vincek D. 2011. Ethnobotanical study on traditional uses of wild medicinal plants in Prokletije Mountains (Montenegro). Journal of Ethnopharmacology, 133(1): 97-107.

Piggot TJ, Holdbrook DA, Khalid S. 2011. Electroporation of the E. coli and S. Aureus Membranes: Molecular Dynamics Simulations of Complex Bacterial Membranes. Journal of Physical Chemistry B, 115: 13381-13388.

Riaz M, Rasool N, Bukhari IH, Rizwan K, Zubair M, Javed F, Qayyum HMA. 2012. Antioxidant, Antimicrobial Activity and GC-MS Analysis of Russelia equsetiformis Essential Oils. Oxidation Communications, 35(4): 1027-1037.

Samusenko AL. 2008. Investigation of antioxidant activity of essential oils from lemon, pink grapefruit, coriander, clove and its mixtures by capillary gas chromatography. Modern Tendencies in Organic and Bioorganic Chemistry: Today and Tomorrow, 397.

Sarikurkcu C, Sabih OM, Cakir A, Eskici M, Mete E. 2013. GC/MS Evaluation and In Vitro Antioxidant Activity of Essential Oil and Solvent Extracts of an Endemic Plant Used as Folk Remedy in Turkey: Phlomis bourgaei Boiss. Evidence-Based Complementary and Alternative Medicine.

Shahzad F, Zubair M, Rizwan K, Rassol N, Tareen RB, Riaz M, Zia-Ul-Haq M. 2015. Evaluation of Biological Activities and GC-MS Analysis of Zygophyllum eurypterum. Oxidation Communications, 38(4 A): 1978-1994.

Willcox JK, Ash SL, Catignani GL. 2004. Antioxidants and prevention of chronic disease. Critical reviews in food science and nutrition, 44(4): 275-295. 